\title{
"Ana Malie" The Traditional Buginise Song Lyrics in Discourse Analysis
}

\author{
Nina Kardina ${ }^{1 *}$ and Ismail ${ }^{2}$ \\ 1,2 Department of English Language Education, Universitas Muhammadiyah Parepare, Indonesia \\ *kardinanina 78@gmail.com
}

\begin{abstract}
This study aimed to find out discourse analysis of traditional Buginese songs through elements used in the song.By analysing the lyrics of the song and focuses on the discourse widely used in the song.The study uses qualitative descriptive method.Some discourse devices that used are cohesion, coherence, intentionality, acceptability, informativeness, situationality, and intertextuality. In this song the cohesion of each part of the sentence does not appear, it is because the sentences depend on each other.The coherence in this song is clear enough because the meaning of each part of the sentences can be easily understood. The writer's intentionality stated in a clear word that the writer used in each of the sentences.In acceptable devices the song is considered acceptable because the song uses phrases or words that are commonly used and known by the society. The informativeness we can gain from this song is the story about a mother who feels sorry about her son's fate in this world, it is measured by constituting some sequence of utterances that contain information. In this song, situationality can be measured from the level of coherence and cohesiveness. Some cohesive markers in the song were not available.The sentences in the song are standalone but whether it is coherence or not, for the researcher its coherence. Intertextuality is the relation between texts that are inflicted by means of quotations and allusion The intention of the song writer was explicitly stated. The moral value that is immersed in the song gives a huge lesson of real life situations.
\end{abstract}

Key words: Discourse analysis, element, lyric, traditional Buginese

\section{Introduction}

In recent years, one of the linguistic domains having a great number of linguists have given attention to is the text grammar or discourse. Discourse analysis is an increasingly popular and important area of language study. It discusses not the lonely language itself but also how it relates with society, culture, and thought. It is used to describe activities in several disciplines such as linguistics, sociolinguistics, and psycholinguistics. The term discourse analysis was first employed by Zelling Harris as the name for a method for the analysis of the connected descriptive linguistics beyond the limit of a single sentence at a time and correlating culture and language: [1] In terms of grammatical hierarchy discourse have the highest level of study that lies in what it is that makes texts meaningful and coherent and has generally been defined as anything "beyond the sentence" [2]. In every discourse type, it is essential to make the relationship between the events very clear-what event caused what other event, which of two events occurred first, 
which is an explanation of a whole series of subsequent events, and so forth [3]. One starting point is the following quotation of discourse analysis: discourse analysis is something concerned with language use beyond the boundaries of an utterance, then something concerned with the interrelationships between language and society [4], and the last one is something concerned with the interactive or dialogic properties of everyday communication [5]. Discourse is a linguistic text with a complete set of elements and bigger than the sentence or clause with the high intensity of cohesion or coherent.Some experts have already given the best hints for explaining the definition of discourse. They are George Yule, Sara Mills, Roger Fowler, David Crystal, Geoffrey Leech and Michael Short, Geoffrey Hawthorn, Michel Foucault and Michael Stubbs. Yule defined discourse as a language beyond the sentence and the analysis of discourse is concerned with the study of language [6].

Discourse analysis focuses on the structure that naturally occurs in spoken language [7]. It can be seen in daily conversation including speeches and interviews. Meanwhile, the discourse analysis in written text merely focuses on its structure. For instance, it can be seen in essays, articles, journals, novels and road signs. Another purpose of why we study discourse analysis is for the educators to have a good schemata in determining how good the text works. So we can focus on teaching our students writing/speaking strategies. As for critical analysis, to discover the meaning of a text which is not obviously stated in the text will deeply enlarge their preconceptions about a text. There are various levels or dimensions of discourse, such as: sounds (intonation, etc.), gestures, syntax, the lexicon, style, rhetoric, meanings, speech acts, moves, strategies, turns, and other aspects of interaction, Genres of discourse (various types of discourse in politics, the media, education, science, business, etc; The relations between discourse and the emergence of syntactic structure; The relations between text (discourse) and context; The relations between discourse and power; The relations between discourse and interaction [8]. Likewise, in social discourse, songs become intelligible to the audience due to some cohesive devices linking all or a series of events together [9]. That is to say, the text-forming devices could constitute a succession of events chronologically, and whenever the audience can grasp the overall text's accurate interpretation, $\mathrm{s} / \mathrm{he}$ is also able to appreciate the value of the song.

Songs are universal things that everybody knows and for 21st generation it is one of things that will give meaning in their way to find their identity. Lyrics in the song will reveal some meaning that will enable the listener or reader to find what the writer wants. In general song can reflect many things in life and the value of life is also found in a song. When a songwriter creates a song, he or she tends to have special meanings and thoughts attached to it, which he or she aims to be understood and accepted by the audience and listeners [10]. Lyrics in the song are not only the arrangement of words into sentence, but also the representation of the composer's emotion and intention to describe their feelings such as love, struggle, trouble, jealousy, peace, antisocial, feeling etc. There are some messages sent by the singer or composer to the listener with specific situation or context in song lyrics. Through a song, composers can express their feelings such as expressing kindness, giving suggestion, or solving love affairs.

Related to the previous paragraph, the lyrics of song become a way of communicating. Basically, song lyrics could be said as a part of discourse. Therefore, it is possible to analyse the discourse of song lyrics. Songs represent a typical discourse which has a purpose to entertain anyone who listens to them. Since songs are basically interpretive and deconstructing texts, they have the purpose to expand the singers or composers' horizons, and make the audience realise the singer or composer's acknowledgement and his/her motivations. In Lyman's term, a discourse and especially a text are sequences of connected sentences or utterances [11]. It can also be in the form by which a sender communicates a message to a receiver or the function. A text is non-communicative if the criteria do not apply to it. Viewed from this topic, seven criteria are given for textuality.They are criteria that a sequence of sentences must meet in order to be qualified as a text. Seven criteria of textuality consist of cohesion, coherence, intentionality, acceptability, informativeness, situationality, and intertextuality. Cohesion is the connection result when the interpretation of a textual element is dependent on another element in a text. Coherence is one part of the aspect that supports the unity received in a text. It is a logical sequence that is understandable by the readers. Coherence texts make sense to the reader. Intentionality refers to the composer's intentions in the song. Acceptability and informativeness constitute a sequence of utterances acceptable to the intended audience that contain information. Situationality considers the situation deals with a sequence related by form of meaning to other sequences of sentences. The criteria are important to discourse analysis. So in this analysis there are seven criteria to be taken as the discourse measurement of this song. They are: cohesion, coherence, intentionality, acceptability, informativeness, situationality, and intertextuality

Kucapu kucampakko Transcript of Ana Malie Song

Ana Malie (Anak Yatim) Originally written by: Andi Rasyid

Ku ucapu kucampakko

Paraddeni ro nyawamu

O... ana aja muterri

Kupakkuru sumangemu

O... ana aja muterri

Kupakkuru sumangemu

Ku ucapu kucampakko

Pareddeni ro nyawamu 


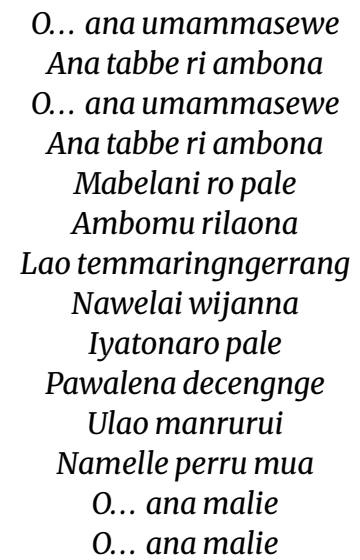

The English Version of Ana Malie Song

$$
\begin{gathered}
\text { I will wipe and pat you } \\
\text { Calm your heart... } \\
\text { Oh my dear child... don't cry } \\
\text { Boost your spirit, } \\
\text { Oh my dear child, don't cry, I'll cheer you up } \\
\text { Oh my dear child..don't cry.. I will rub you } \\
\text { I will wipe and pat you } \\
\text { Calm your heart, } \\
\text { Oh my dear child... } \\
\text { Oh my dear child... } \\
\text { The child who was abandoned by his father } \\
\text { The lonely child who's abandoned by his father } \\
\text { It turns out that your father has gone far away } \\
\text { Go and leave his family } \\
\text { Go and never remember to be home } \\
\text { Go far ..far away from his family. } \\
\text { Maybe that's the payback of my kindness } \\
\text { After I have followed him wherever he goes } \\
\text { But he cruelly left me in this place } \\
\text { Oh my dearest child... } \\
\text { My dearest son } \\
\text { I will calm your heart } \\
\text { Calm your feelings my dear... } \\
\text { It's enough to give to the world } \\
\text { My son who was wasted in the world } \\
\text { My son who was abandoned by his father } \\
\text { The lost and lonely child in the world }
\end{gathered}
$$

\section{Methodology}

This study uses a qualitative descriptive method in the song's lyrics. Whereas, a qualitative approach relates to the data which is not in the form of numbers, but in words and pictures instead, using statements, sentences, quotations, descriptions or manuscripts of interviews, photos, and videotapes [12]. This is because the descriptive method demands a researcher to compile the text-reference-based data by encompassing the step-by-step process worked to assemble information. In this case, the process began by studying the lyrics.The data was collected by identifying the manuscript of the Buginese song Ana Malie lyrics and exploring some related scientific articles,literature,journal about song in discourse. Data collected with reading-listening and note-taking techniques. Data analysis techniques through the stages of identification, classification, analysis, and description [13]..The subject of this research was the Ana Malie song lyrics.The song was hereditary sung by Buginese people and until now it is showing its existence. The researcher built some research questions below: 1) What are the configurations of discourse of song lyrics in Buginese song Ana Malie?; 2) What are the purposes of the composer in Ana Malie's traditional song?. Based on the problem statement, the researcher has the following objectives: 1) To identify the elements of song lyrics as discourse in Ana Malie song; 2) To describe the composer's intention in Song Lyrics Ana Malie song. 


\title{
Findings and Discussion
}

\author{
Discourse Analysis of Ana Malie Song
}

As the writer has said above, the song will be analysed by some criteria to be taken as the discourse measurement of this song. They are: cohesion, coherence, intentionality, acceptability, informativeness, situationality, and intertextuality

\section{Cohesion}

In this song the cohesion of each part of the sentence does not appear.The writer analysed each of the sentence's depending on each other. The song writer rarely used connector, conjunction, pronunciation, etc. But to differentiate between subject, predicate or object in sentences can be so easy because they can be seen clearly in the sentences. The song writer used repeated words several times. Even though it seems that the songwriter wants to emphasise his intention, it seems to be redundant. Coherence

\section{Coherence}

The coherence in this song is presumably clear enough. It is because the meaning of each part of the sentence can be easily understood. This song can be easily understood from all levels of ages or listeners. We should not need to have deep insight or interpretation because the meaning of the song is stated. People who read the transcript of this song will understand the sad story in this song because it is described brightly with each word in this song.

\section{Intentionality}

Intentionality is the power of minds to be about something: to represent or to stand for things, properties and states of affairs [14]. In this song, the writer stated his purpose in a clear word that he/she used in each of the sentences. We can define that there are two persons in this song. They are a mother who really cares and loves her son. The second person in this song is the woman's son. We can conclude that he is a really patient boy who has to deal with the cruel world. He's been delivered to the world without knowing where his father is. Although he is lonely, he has the kindest and toughest woman beside him that is her mother.

\section{Acceptability}

Acceptability is the characteristic of a thing being subject to acceptance for some purpose. A thing is acceptable if it is sufficient to serve the purpose for which it is provided, even if it is far less usable for this purpose than the ideal example. A thing is unacceptable (or has the characteristic of unacceptability) if it deviates so far from the ideal that it is no longer sufficient to serve the desired purpose, or if it goes against that purpose. From a logical perspective, a thing can be said to be acceptable if it has no characteristics that make it unacceptable [15]. In this song acceptability was measured to constitute a sequence of utterances acceptable to the intended audience that contain information. Several utterances used in this song were merely general.This means the writer of the song used some common words in the song. There are two things that might be the reason why the writer used a common phrase, firstly because he/she wants the song to be acceptable in all levels of ages. It means the message of the song was understandable. Second, the story of the song often happened in society. The condition stated in the song can be found easily in the middle of our neighbourhood. So it is reasonable to use the common phrase or words in order for the song to be acceptable in the society.

\section{Informativeness}

The same as for acceptability, informativeness is also measured by constituting a sequence of utterance that is acceptable to the intended audience that contains information. We can say that informativeness means whether or not the use of some phrases or words, or sentence can give us some hints in interpreting the song. Some phrases or words used in the song will reveal information about the song. For example, the sentence "my dear child". It means that this song was sung by a woman, in this case a mother. Another sentence like "my abandoned and lonely child" shows us that her child was left behind by his father ever since he was little. In the sentence "Maybe that's the payback of my kindness after I have followed him wherever he goes ... but he cruelly left me in this place". This gives us information that after she has followed her husband and left her family. But then her husband left her with her child without any news. Overall, the information that we can gain from this song is this is the story about a mother who feels sorry about her son's fate in this world.

\section{Situationality}

Situationality concerns the factors which make a text relevant to a situation of occurrence [16]. The situation in which a text is exchanged influences the comprehension of the text. In this song, situationality can be measured from the level of coherence and cohesiveness. Some cohesive markers in the song were not available. The sentences in the song are standalone but whether it is coherence or not, for the researcher it is coherence. If we connect it with the situationality of the song, then we can conclude that this song is understandable. 


\section{Intertextuality}

Intertextuality is the shaping of a text's meaning by another text. It is the interconnection between similar or related works of literature that reflect and influence an audience's interpretation of the text. Intertextuality is the relation between texts that are inflicted by means of quotations and allusion. These variations depend on two key factors: the intention of the writer, and the significance of the reference. The distinctions between these types and those differences between categories are not absolute and exclusive but instead, are manipulated in a way that allows them to co-exist within the same text [17]. As for this song, we rarely found some quotation or allusion. It is because all phrases and sentences in this song are explicitly stated. The writer didn't use any allusion. We can easily interpret the song only by reading the transcript or listening to the song. The intention of the song writer was explicitly stated.

\section{Moral Value of Ana Malie Song}

Even Though there were not many things that can be considered as the moral value of the Ana Malie song. But we can take some message from this song: 1) Overall this song shows that a love from a mother is beyond compare; 2 ) From the song we can conclude that the mother is a loving care creature whose been willing to do everything for her children;3) Even though we are suffering in this world but we always have to fight for live; 4) Sometimes what we give is not as what we expect in return.

\section{Conclusion}

Song is one universal thing that everybody knows. Through lyrics in the song will reveal some meaning that will enable the listener or reader to find what the writer wants. In general songs can reflect many things in life and the value of life is also found in a song. In the song of Ana Malie, a Buginese song, we can share some new knowledge about the song through discourse analysis. Some elements of discourse found in the song are: cohesion, coherence, intentionality, situationally, acceptability, informativeness, and intertextuality. The song itself reveals a story about a woman that feels pity for her son because of his fate in this world. The phrases and sentences that were used in the song explicitly stated the meaning inside the song. So instead of having deep insight about the meaning of this song we can directly understand the story of the song directly. Because it is easy to understand and implicitly reveals the writer's intention in the song.

\section{References}

[1] Z. Harriz." Discourse analysis". Published By: Linguistic Society of America Journal Article. Vol. 28, 1952

[2] G. Cook. "Discourse and Literature" in The Interplay of Form and Mind. Oxford: Oxford University Press, 1994.

[3] K. Callow, Discourse Considerations in Translating the Word of God. Zondervan, Grand Rapids, 1974.

[4] M. Stubbs, Discourse Analysis: The Sociolinguistic Analysis of Natural Language. Chicago, IL: The University of Chicago Press, 1983.

[5] Tarigan, G. Henry, Pengajaran Wacana. Bandung: PT. Angkasa, 2009

[6] G. Yule, The Study of Language. New York: Cambridge University, 2010

[7] Aisyah, "An analysis of teachers' talk in an EFL classroom" In Journal of English and Education, 2016.

[8] T. P. Inike, "We Shall Overcome" A Humanity Song by Roger Waters: Critical Discourse Analysis. In Humaniora, vol.30, 2018.

[9] D. Schiffrin, D. Tannen, H.E. Heidi. "Critical discourse analysis". In (eds.). The Handbook of Discourse Analysis. Malden, Massachusetts, USA: Blackwell Publishers Ltd., 2001.

[10] J. Renkema, Discourse Studies: An Introductory Textbook. Amsterdam: John Benjamins Publishing Company,1993.

[11] A. A. Andriyani, K. Andi. "Representasi Makna Lagu Bugis Mappadendang Melalui Pendekatan Hermeneutika".CLLT Journal. pp. 418-423, 2017

[12] Moleong .Metodologi Penelitian Kualitatif. Edisi Revisi. Jawa Barat: PT. Remaja Rosdakarya, 2007.

[13] Gunawan, et. al, "Figurative language used in Blackpink featuring Selena Gomez's song lyric "Ice Cream": A discourse analysis. Journal of Applied studies in language vol.5. 202, pp 1-9, June 2021 
[14] Text_linguistics, August 2021 ( online ) available: Wikipedia. /https://en.wikipedia.org/wiki/

[15] Text_linguistics, August 2021 ( online ) available: Wikipedia. /https://en.wikipedia.org/wiki/

[16] “Text_linguistics, August 2021 ( online ) available: Wikipedia. /https://en.wikipedia.org/wiki/

[17] Text_linguistics, August 2021 ( online ) available: Wikipedia. /https ://en.wikipedia.org/wiki/

[18] M. Kaźmierczak. "Intertextuality as Translation Problem: Explicitness, Recognisability and the Case of "Literatures of Smaller Nations"" . Russian Journal of Linguistics, 2019. 